Florida International University FIU Digital Commons

$4-1981$

\title{
A Study to Investigate The Hotel Manager's Reaction to The Increasing Electricity Rates in the City of Miami
}

Jamal Feerasta

Florida International University

DOI: $10.25148 /$ etd.FI15101356

Follow this and additional works at: https://digitalcommons.fiu.edu/etd

Part of the Business Administration, Management, and Operations Commons, and the Hospitality Administration and Management Commons

\section{Recommended Citation}

Feerasta, Jamal, "A Study to Investigate The Hotel Manager's Reaction to The Increasing Electricity Rates in the City of Miami" (1981). FIU Electronic Theses and Dissertations. 3499.

https://digitalcommons.fiu.edu/etd/3499 
A STUDY TO INVESTIGATE THE HOTEL

MANAGER'S REACTION TO THE INCREASING

ELECTRICITY RATES IN THE CITY OF MIAMI

BY

Jamal Eeerasta

A THESIS

Submitted in partial fulfillment of the requirements for the degree of

Master of Science

in

The School of Hospitality Management

at

Florida International University

Committee in charge:

Dr. Donald Greenaway

Professor Fritz Hagenmyer

April 1981 
To Professors: Donald Greenaway

Fritz Hagenmyer

This thesis, having been approved in respect to form and mechanical execution, is referred to you for judgment upon its merit.

Déan Gerald W. Lattin

School of Hospitality Management

The thesis of Jamal Feerasta is approved.

protessor

Protessor

Date of Examination: April 1981 
Page

ACKNOWLEDGEMENT . . . . . . . . . . . . iv

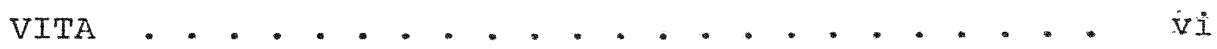

THE PROBLEM AND ITS SETTINGS

The Statement of the Problem . . . . . . . 1

The Statement of the Subproblem . . . . . . I 1

The Hypotheses .. . . . . . . . . . . . . 1

The Delimitations . . . . . . . . . . . 1

The Assumptions .............. . . 2

The Importance of the Study . . . . . . . 2

THE REVIEW OF THE RELATED LITERATURE

Energy Consumption - A National Overview . . . 4

Florida . . . . . . . . . . . . . 6

Miami . . . . . . . . . . . . . 7

U.S. Lodging Industry ........... . 10

Florida Lodging Industry . . . . . . . . . . 14

Summary of Case Studies . . . . . . . . 17

THE RESEARCH METHODOLOGY ........... 20

THE RESULTS

Hypothesis I. . . . . . . . . . 22

Hypothesis II . . . . . . . . . 25

Other Findings... . . . . . . . . . 29

SUMMARY OF THE RESULTS . . . . . . . . 29

SELECTED BIBLIOGRAPHY . . . . . . . . . 31

APPENDICES ...................... 33 


\section{LIST OF TABLES AND GRAPHS}

TABLE 1 U.S. Energy Consumption and Electric

Page

Generation for 1973-79 . . . . . . . 4

TABLE 2 Composite Average of All Fuels By

the Florida Electric Utility Industry * • 7

TABLE 3 Summary of Total Customers and

Commercial Customers, Kwh and kwd . . . 9

TABLE 4 Energy Use By the Lodging Properties -

Energy Technical Center Research . . . . 12

TABLE 5 Average Energy Costs of U.S.

Lodging Properties.......... 13

TABLE 6 Energy Consumption By Lodging

Properties in Florida . . . . . . . 15

TABLE 7 The Lodging Industry Dollar, U.S.

versus Florida, Where It Went . . . . 16

TABLE 8 Electric Cost as a Percentage of Total Energy Cost . . . . . . . . 23

TABLE 9 Electricity Cost Increases . . . . . 24

TABLE 10 Effect of Electricity cost on

Building Operation Maintenance cost . . 25

\section{GRAPH}

FIGURE 1 Efficiency of Water Heaters and Gas

Dryers--La Quinta Motor Inns, Case Study . 19 


\section{APPENDIX}

Page

APPENDIX A ENERGY SOURCE BY FUEL TYPE USED BY FLORIDA POWER AND LIGHT CORPORATION . •

APPENDIX B FLORIDA POWER AND LIGHT CORPORATION, CUSTOMERS, KWH SALES AND MEGAWATT CAPABILITY

APPENDIX C FUEL ADJUSTMENTS . . . . . . . . . 36

APPENDIX D DADE COUNTY TOURIST ACCOMMODATION

FACILITIES . . . . . . . . . 39

APPENDIX E MAP OF THE CITY OF MIAMI, FLORIDA . . . . 40

APPENDIX F QUESTIONNAIRE . . . . . . . . . . . 41 Survey Results

APPENDIX G METHOD OF DETERMINING EXACT ENERGY CONSUMPTION BY VARIOUS DEPARTMENTS • . . 47

APPENDIX H ENERGY CONSUMPTION ALLOCATION . . . . . 48

APPENDIX I ELECTRICITY USAGE (\%) BY ROOMS AND OTHER DEPARTMENTS . . . . . . . . . . 4 48

APPENDIX J ENERGY BUDGETING . . . . . . . . . . . 49

$\begin{array}{ll}\text { APPENDIX K } & \text { GUIDELINES CORPORATE OFFICE FOR } \\ & \text { ROI/PAYBACK PERIODS . . . . . . . . . . } 49\end{array}$

APPENDIX L FORMS OF ENERGY USED . . . . . . . . . 50

APPENDIX M PERCENTAGE OF EACH SOURCE OF ENERGY USED . . . . . . . . . . . . 50 


\section{ACKNOWLEDGEMENTS}

I would like to take this opportunity to express my deep appreciation to the many faculty members who have helped me in the preparation of this thesis and who have made my attendance at Florida International University one of personal growth. Special thanks to Dean Gerald Lattin and Associate Dean Anthony Marshall for their help during my stay here at Florida International University.

I would like to particularly thank Professors Donald Greenaway and Fritz Hagenmeyer who have given me inspiration, assistance in gathering the data and inestimable advice. This endeavour would not have been completed without their guidance and direction.

I would also like to thank Mr. K. A. Quaranta, Customer Service Coordinator, and Mr. John C. Evelyn, Power Services, of Florida Power and Light Corporation for their interest and time towards the completion of this study. And the following hotel managements who have provided data used in this study:

I. Miami Marriott Hotel

1201 N.W. 42nd Avenue Miami, FI

2. Miami Airport Inn 1550 N.W. Le Jeune Road Miami, FL

3. Airport Lakes-Holiday Inn 1101 N.W. 57th Avenue Miami, FL 
4. Sheraton Riverhouse 3900 N.W. 21st Street Miami, FL

5. Ramada Inn

3941 N.W. 22nd street Miami, FL

6. Inter-Continental Miami 801 S. Bayshore Drive Miami, Fis

7. Columbus Hotel 312 N.E. Ist Street Miami, FL

8. Howard Johnson's 299 S.E. 2nd Avenue Miami, FL

9. Marina Park Hotel 340 Biscayne Boulevard Miami, FL 
VITA 


\section{VITA}

The author was born in Rangoon, Burma on July 16, 1952. His family migrated to Bangla Desh (then East Pakistan) in 1954. During the Bangla Desh Revolution his family migrated to Karachi, Pakistan. In 1977, the author completed his B.A. (Honors) in Economics from the University of Karachi. Under the Economics Research Center of the University, he conducted a study dealing with Pakistan's Hospitality Industry.

In March 1978, he joined Florida International University's, School of Hospitality Management. He completed the B.S. program in Hotel Management in June 1979 and was recruited by the Charley Brown's restaurant chain for their training program in Restaurant Management. In September 1979, he joined the M.S. program in Hotel Management at F.I.U. Upon the completion of this program, he will start as a Restaurant Management trainee with the Marriott Hotel chain. 
THE PROBLEM AND ITS SETTINGS 
STATEMENT OF THE PROBLEM

The purpose of the study is to investigate the hotel manager's reaction to the increasing electricity rates in the City of Miami.

\section{STATEMENT OF THE SUBPROBLEMS}

The first subproblem. The first subproblem is to determine the hotel manager's awareness to the trend of increasing electricity rates in the City of Miami.

The second subproblem. The second subproblem is to interpret the meaning of hotel management's awareness or lack of awareness of the implication of constant increases in electric energy costs.

\section{THE HYPOTHESIS}

The first hypothesis is that the management is aware of the increasing cost of electricity and its impact on the property's operations.

The second hypothesis is that the management does not have any specific or concrete policies to control the consumption of electricity.

\section{THE DELIMITATIONS}

The study will explore Miami hotel managers" reactions to the increasing electricity expenses due to the increasing 
electricity rates,

No attempt will be made to investigate conservation. techniques or the efficient use of electricity.

The study will not suggest any possible solutions to the pending problems.

Hotels having 150 rooms or more will be considered for the study.

\section{ASSUMPTIONS}

The first assumption. The first assumption is that the basic electricity rate structure and the ancillary rate will increase in the coming years.

The second assumption. The second assumption is that the hotels will be faced with increasing electricity expenses.

THE IMPORTANCE OF THE STUDY

The "U. S. Lodging Industry, 1980" report published by Laventhol and Horwath indicates that the average energy costs of hotels was 4.3 percent of total costs in 1979 , compared to 4.5 percent in 1978. The reports indicate that in 1979 the average energy costs increased by 11.1 percent over 1978 .

The energy usage components of a typical hotel consists of electricity, gas, and fuel oil. Of these, electricity constitutes the major source and cost component.

Though nationally, coal is followed by fuel oil as a 
major source of electric power generation, and the use of oil as a source of power has declined, the dramatic increase in the price of oil has aggravated the situation. This is reflected in the increasing electricity rate structure as represented in the fuel adjustment charges.

over fifty percent of the electricity generated by the Florida Power and Light Corporation (FP\&L) is produced by fuel oil. Due to the increases in the price of oil the electricity rates have also increased, nearly at the inflation level, i.e., approximately by ten percent in the recent years. There is no indication that the dual trends of increasing rates and periodic shortages will subside. Since electricity costs constitute the major cost component of energy usage by a typical hotel, it is imperative that an investigation be conducted to determine the level of management's awareness to the trend of increasing electricity rates and their reactions.

In the past, very few in-depth studies have been done in the area of management's view of electricity rates and its impact on the hotel's operation in a given geographical area. 
THE REVIEW OF THE RELATED IITERATURE

Energy Consumption - A National Overview

The United States, with six percent of the World's population, uses about 30 percent of the World's energy.

"The share of the nation's gross energy consumption accounted for by electricity generation rose to 31.2 percent in 1979, again setting a new record as it almost invariably does each year. The 1979 rise resulted from a 2.3 percent year to year rise in electricity generation in the face of a 2.5 percent drop in U. S. energy consumption, as indicated by the table below."I

TABLE 1

U. S. Energy Consumption and Electric Generation for 1973-79

$\begin{array}{ccccr}\begin{array}{c}\text { Energy } \\ \text { Consunption } \\ \text { Level (Q Btu) }\end{array} & \begin{array}{c}\text { Electric } \\ \text { Change } \\ (\%)\end{array} & \begin{array}{c}\text { Lonsumption } \\ \text { Level (Q Btu) }\end{array} & \begin{array}{c}\text { Electric } \\ \text { Change } \\ (\%)\end{array} & \text { (\%) } \\ 74.61 & 4.2 & 20.00 & 6.4 & 26.8 \\ 72.76 & -2.5 & 20.14 & 0.7 & 27.7 \\ 70.71 & -2.8 & 20.41 & 1.3 & 28.8 \\ 74.51 & 5.4 & 21.54 & 5.5 & 28.9 \\ 76.39 & 2.5 & 22.83 & 6.0 & 29.0 \\ 78.15 & 2.3 & 23.42 & 2.6 & 30.0 \\ 78.20 & 0.1 & 24.43 & 4.3 & 31.2\end{array}$

Q Btu - quadrillion Btu.

Source: U. S. Department of Energy, Monthly Energy Review.

${ }^{1}$ Studness, Charles M., 'Electric Demand and Aggregate U. S. Energy Consumption' Financial News and Comment. Public Utilities Fortnightly, July 31,1980, p. 38. 
The 1979 increase in the share of energy being consumed through electric generation reflects a continuation of a methodical historical trend. Significantly, the shift in the nation's energy priorities and the sharp upward trend in energy prices initiated by the Arab oil embargo have had little impact on this trend. It is interesting to note that electric generation's share of energy consumption has increased from 26.8 percent in 1973 to 31.2 percent in 1979.

In part, the continuing rise of electric generation's share of energy consumption stems from the structure of energy prices encouraging a shift to electric usage, as electric rates have increased less since 1973 than the price of othex forms of energy. For instance, "between 1973 and 1979 the price of residential electricity increased by 11.2 percent in constant dollars, while prices of residential natural gas jumped 58 percent and gasoline rose 36.3 percent. Prices of residential heating oil, which data are not available before 1974, rose 38.6 percent in constant dollars during 1974-79; the rise was close to 60 percent." 2

The heavy dependence of U. S. on imported oil, has made the United States sensitive to increasing oil prices. It is virtually certain that the price of oil will steadily increase over the years. At the end of 1978, the price of OPEC Oil averaged $\$ 12.50$ a barrel. By the end of 1979 , this price approached $\$ 25.00$ a barrel. During 1979 alone, higher 
prices caused the 8.4 million barrels a day imports to cost some $\$ 35$ billion more on annual basis than in 1978. Today the price of oil is around $\$ 36$ a barrel. Keeping in view the fact that electricity generation accounts for nearly 7 percent of the total oil consumption in the country, the plight of the utility companies has been aggravated by regulations and inflation, which has made the adding of new capacity prohibitively expensive. According to Edison Electric Institute, the average Capital cost of a coal-fired plant has jumped from $\$ 144$ per Kwh in 1970 to an estimated $\$ 1096$ per Kwh today. For nuclear capacity the comparable numbers are $\$ 165$ and $\$ 1861$. The soaring cost of financing and running utilities have prompted companies to seek rate increases. In many states, rate increases have been denied outright by Public Utility Commissions (PUC), while average increases have hovered around 50 percent to 60 percent of the original request. Putting all these factors together, the implication is clear that the public will inevitably pay for the utilities problems. And, the reckoning may not be far away.

FLORIDA

Keeping the above discussion in view, any increase in the price of oil or a shortfall in the supply of oil, has and would add substantially to the cost of operations. This situation becomes acute and critical in the case of Florida. 
Fuel oil is the major source of electric generation in Florida. In 1979 it accounted for nearly 47.8 percent followed by coal (19.4\%), nuclear power (16.3\%), natural gas (16.06\%) and hydro (.27\%). Florida ranks fourth in the use of oil for electricity power generation.

According to the statistics available on the composite averages of all fuels consumed by the Florida Electric Utility Industry, the cost per million Btu and the cost per Net Kwh has increased between the years 1975 to 1979. The cost per million Btu increased from $\$ 148.5$ in 1975 to $\$ 223.9$ in 1979, an increase of nearly 50 percent. The cost per Net Kwh has gone up from $\$ 1.56$ in 1975 to $\$ 2.34$ in 1979, an increase of 50 percent also. This is shown in Table 2.

TABLE 2

\begin{tabular}{lcc} 
Year & Cost/Million BTU & Cost/Net KWH \\
\cline { 3 - 3 } 1975 & $\$ 148.5$ & $\$ 1.56$ \\
1976 & 149.6 & 1.59 \\
1977 & 170.0 & 1.78 \\
1978 & 170.0 & 1.80 \\
1979 & 223.9 & 2.34
\end{tabular}

Source: Statistics of Florida Electric Utility Industry 1979.

MIAMI

Florida Power and Light Corporation (FP\&L) is the sole electricity supplier to the City of Miami. Fuel oil has been and will be the major source of fuel, (nearly 46\%), for the generation of electricity, at least, till the end of the 
decade. However, in the coming years, coal would contribute substantially towards the generation of electricity. This is shown in Appendix A.

Florida Power and Light Corporation estimates that by the year 1989 it would be serving 2.84 million customers compared to 2.07 million customers in 1979, an increase of 37 percent. The estimated sales for the year 1989 is 59.88 billion Kwh compared to 41.97 billion Kwh in 1979, an increase of 43 percent in sales. During the same period, the increase in electricity generation capability is estimated to be up by 29 percent, from 10.96 thousand Mw in 1979 to 15.51 thousand Mw implying adequate supply capacity. This is shown in Appendix B.

Between the years 1975 to 1980, the number of commercial customers served by the FP\&L increased from 173,346 in 1975 to 212,950 in 1980 , up by 22.8 percent. Whereas, the kwh sales was up by 27.3 percent. It is interesting to note that the percentage of commercial customers to total customers did not show any significant shift. However, the Kwh sales for commercial customers as a percentage of total Kwh sales has decreased, clearly implying that the commexcial customers are conserving electricity. These trends are shown in Table 3. The cost of producing electricity has been going up. In 1978,33 cents of every dollar spent, went for the payment of fuel. This amount increased to 41 cents in 1979 and was 44 cents in 1980. These increases were passed on to the cus- 


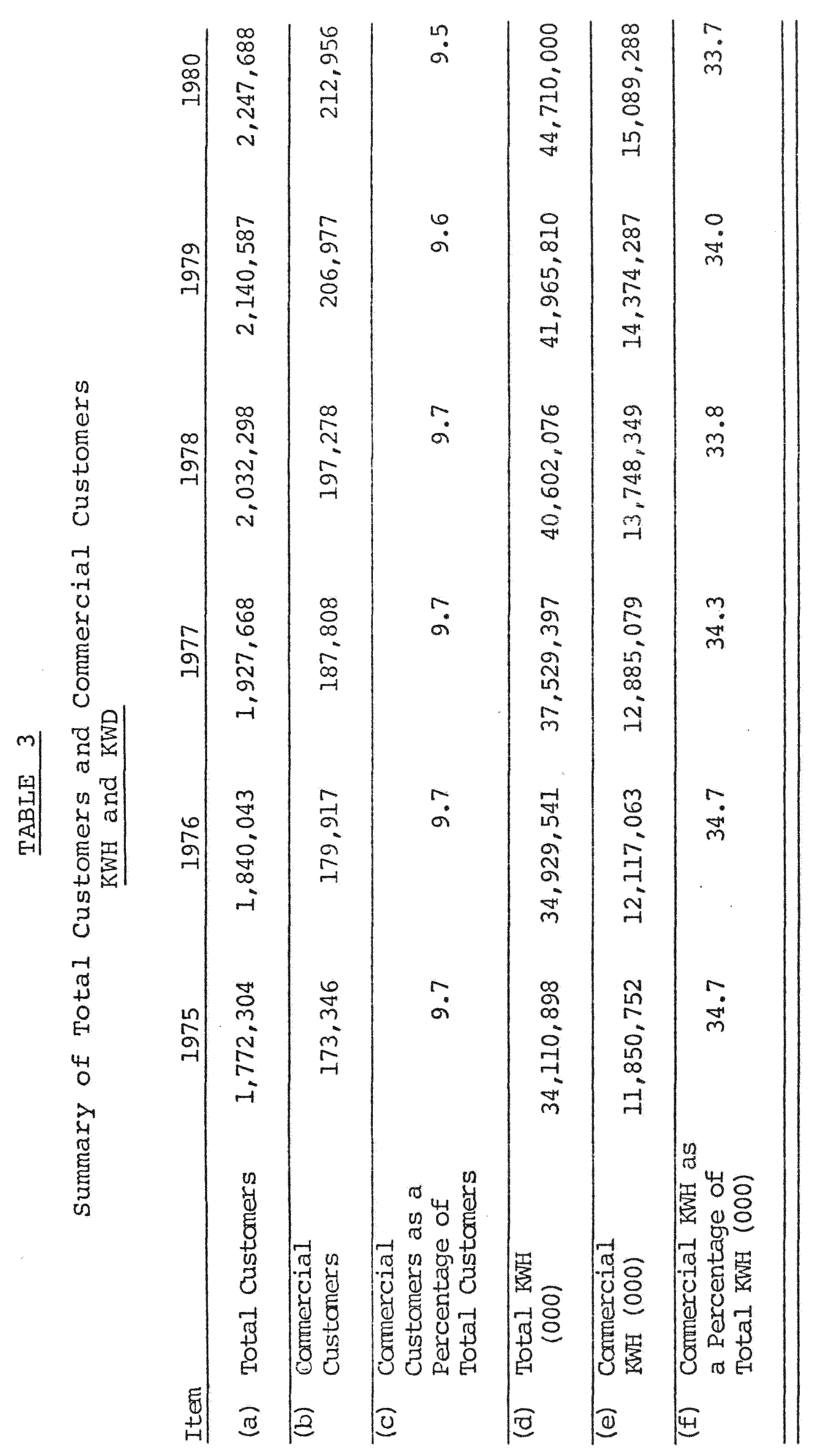


tomers in the form of fuel adjustment charges. The trend of the fuel adjustment charges between 1974 to March 1981 (see Appendix (), shows that fuel adjustment charges have mostly been on the increase. For the period March 31, 1981 to April 1981, the charges were up by $\$ 6.50$ to $\$ 19.50$ per 1000 Kwh. Further increases are scheduled for May 1981.

From the preceding discussion, it is clear that the era of cheap energy is over. When such a situation is considered from the point of hotel operations, it deserves special attention.

LODGING INDUSTRY

To date very little study has been done in the area of electricity rates and hotel management's view of the situation, in a given area or region.

A study was conducted by the Energy Technical Center of the Hospitality, Lodging and Travel Research Foundation, dealing with the analysis of energy use in 284 hotels and motels located in thirty-nine states and the District of Columbia. These 284 properties comprised four percent of American Hotel and Motel Association membership. The report concluded that, "even with the hospitality industry's improvement in energy use over the past three years, the cost of energy has increased at an even greater pace. In 1979, the average annual cost of energy per square foot of property was an estimated $\$ 1.08$. And, in mid-1981, indications are 
that the average cost of energy will continue to increase at a fifteen to twenty percent annual rate. Now, more than ever, increased and effective energy management practices are essential to the continued growth and financial wellbeing of the hospitality industry." ${ }^{3}$ The findings of the study are shown in Table 4.

According to the Laventhol and Horwath's, U.S. Lodging Industry Reports, the energy costs per room have increased between the years 1975 to 1979. However, the energy costs ratio to room sales and total sales have largely declined for all categories of hotels. Table 5 also indicates that the greatest increases in the energy cost per room is for properties having 600 rooms or more. The increase was 2.0 percent between 1977 and 1978 and 14.0 percent between 1978 and 1979. It is interesting to note that when the cost ratio of energy to occupancy is taken into account, the highest increase has taken place in the properties having occupancy of over 80 percent. This increase was by 6.4 percent between 1977 and 1978 and 18.5 percent between 1978 and 1979. However, when energy costs are taken as a ratio to room sales, we see that the ratio to room sales and total sales, have remained consistent or have decreased. This clearly implies that in order to meet the increasing operating

${ }^{3}$ Energy Technical Center, The Hospitality Lodging and Travel Research Foundation, Inc., "Analysis of the Energy Use of 284 Hotels and Motels, 1979," p. ii. 
TABLE 4
Energy Use By the Lodging Properties

1977

1978

1978 versus 1979

(Same Properties)

No. of Properties

210

327

284

284

No. of Guest Rooms

59,648

84,554

68,911

69,368

Total Sq. Ft. (mln)

42.6

52.6

40.4

40.8

Total Energy Use

(Trillions of BTU's)

7.7

8.4

6.2

5.9

BTU/sq. ft./yr.

181,685

158,736

153,308

143,977

Indicated Decrease in

Energy Use:

. . 1978 versus 1977

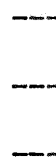

$12.6 \%$

. . .1979 versus 1978
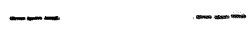

$6.1 \%$

. . 1979 versus 1977
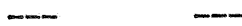

$20.8 \%$

(In considering the above indicated $6.1 \%$ decrease in energy use by 284 hotels and motels, 1979 versus 1978, it should be noted that the American Hotel and Motel Association estimates that the average guest occupancy for 1979 was at 67.8 percent, compared to 65.5 percent in $1978--a n$ increase of 3.5 percent.) 


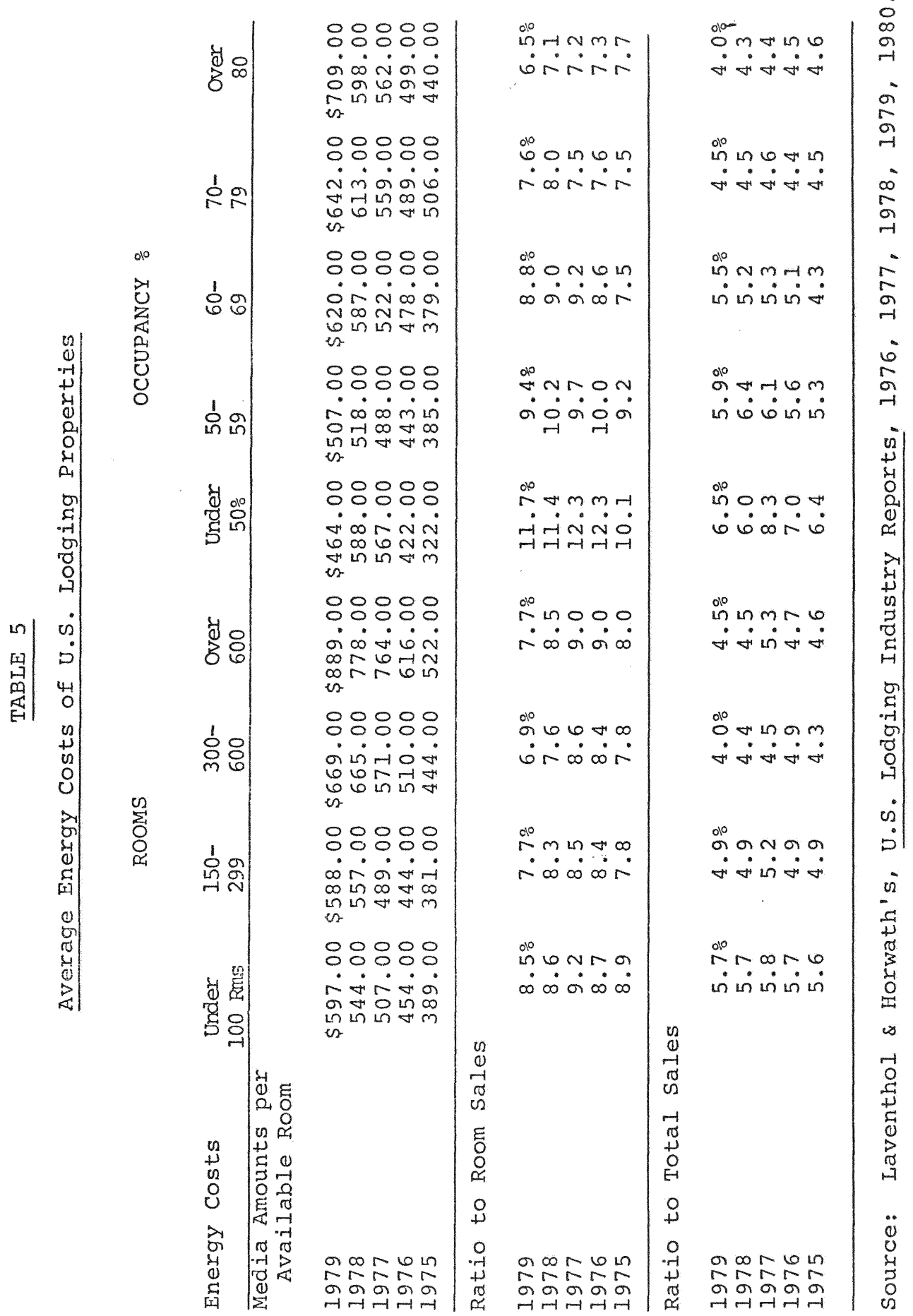


costs, the properties have generally passed on the burden to the guests in the form of higher room rates, etc.

\section{FLORIDA}

In comparing the energy costs per available room for the lodging properties in Florida with that of the national trend, we see that in 1975, 1976, 1977 and 1978 the properties in Florida allocated 27 percent, 10 percent, 7 percent and 13 percent more dollars respectively than the properties in the U. S. as a whole.

In terms of energy costs per occupied room, Florida lodging properties paid 16 percent, 11 percent, 8 percent and 7.6 percent more for the corresponding period. These comparisons are shown in Table 6 . 


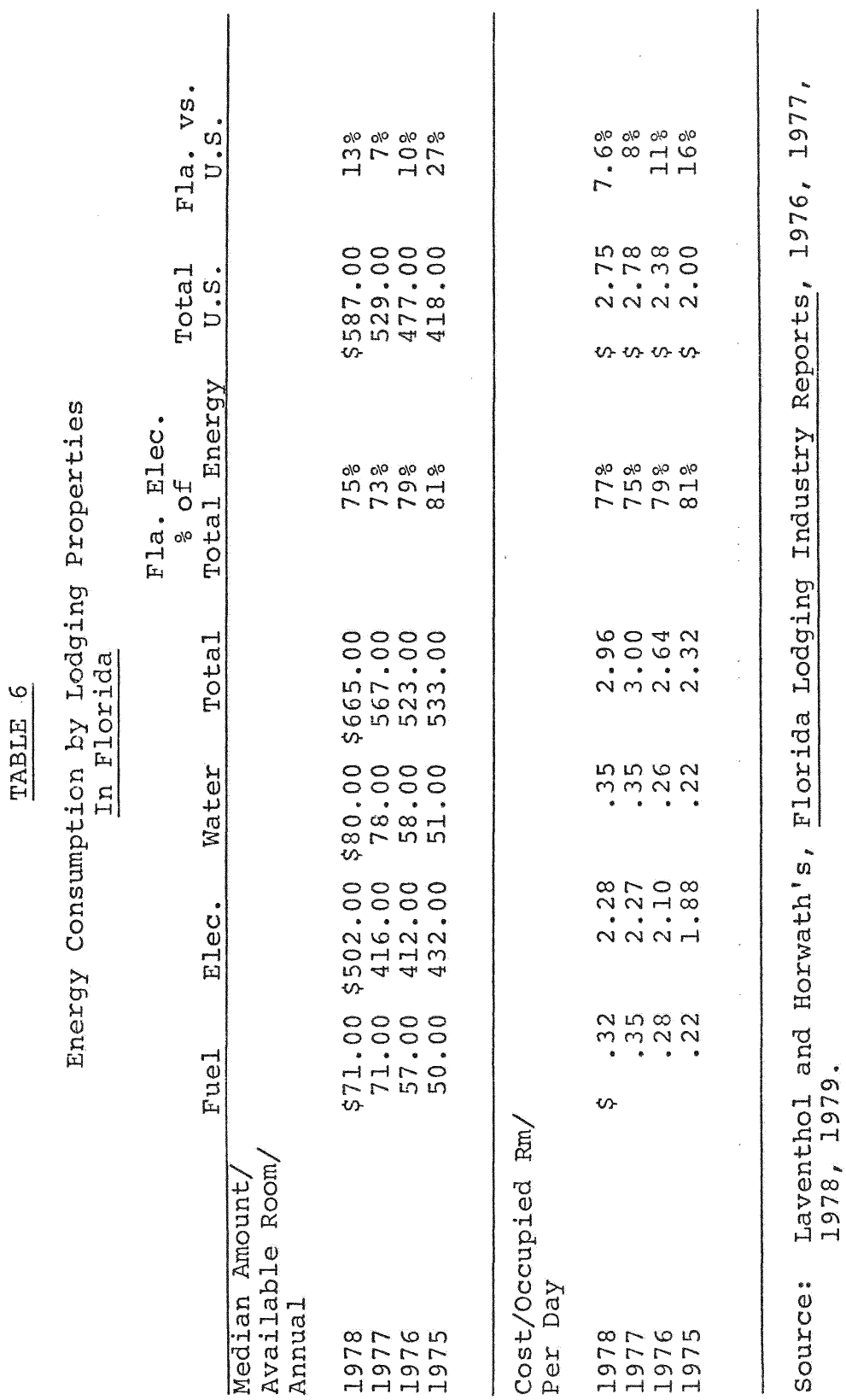




\section{TABLE 7}

The Lodging Industry Dollar, U. S. Versus Florida, where It Went

ENERGY

$$
1978
$$

1977

1966

1975

U.S.

4.5

4.9

4.9

5.0

Florida

10.3

10.1

5.2

6.7

NET INCOME BEFORE TAXES

1978

7.5
1977

5.5

3.4
1976

1975

U.S.

Florida
3.5
3.5

1.6

1.2

Source: Laventhol and Horwath's, Lodging Industry Reports, $1976,1977,1978,1979$.

A comparison between the Florida properties and the National trend for the allocation of energy expenses as a percentage of total sales shows that the Florida properties have been allocating substantially higher amounts between the years 1975 to 1978 . On the other hand, the national net income average before taxes has been higher than for Florida properties. These comparisons are shown in the above Table. The preceeding discussion clearly implies that since the Florida properties have been faced with greater energy 
costs in general and higher electricity costs in particular, compared to the national averages, these properties, in the future, will be faced with higher energy costs. It is imperative that sooner or later the management will have to accept the reality of the situation and take measures to minimize the negative impact.

A study by Professor Redlin of Cornell University's School of Hotel Administration, suggests a method of regression analysis which can be used by the management to project the consumption of utilities more accurately and therefore budget and control the use consumption of utilities more efficiently. However, the study does not take into account the management's views or reactions to the increasing electricity rates.

The importance of management's awareness and reactions to the possible impact of increasing utility costs can be illustrated by the following case studies.

CASE I

La Quinta Motor Inn

La Quinta Motor Inns, Inc., is a San Antonio-based chain of approximately 100 motor inns, averaging about 130 rooms each. The chain spends an average of $\$ 347$ per room per year on utilities. Nothing that goes in the room costs 
more. 4

The chain learned from AH \& MA's Energy Technical Center that electric costs are expected to rise by 11.8 percent in 1978, gas by 17 percent, and oil by 19 percent. The company decided that they must control utility consumption. So they decided to approach utility cost reduction in two ways:

1) more practical operations control, and 2) better utilization of energy-saving technology in construction.

The operations control involves the area of preventive maintenance of the physical plant, equipment, and emphasis on the plant's insulation. As a result of the practical operations approach, it was found that the efficiency of the water heaters and gas dryexs increased by nearly 30 percent. This is shown in Figure 1 on the following page.

In the area of construction technology, La Quinta has been widely publicized as one of the few lodging chains that is experimenting broadly with solar energy. It is also one of the few chains to use heat pumps extensively and other energy-saving construction techniques.

${ }^{4}$ La Quinta Motor Inns, San Antonio, "A Case Study in Energy Management: Controlling the cost of Utilities," Lodging, June 1979, p. 7. 
Figure 1

Inprovements in domestic hot water heating as a result of cleaning combustion chambers, adjusting firing rate, insulating hot water piping.

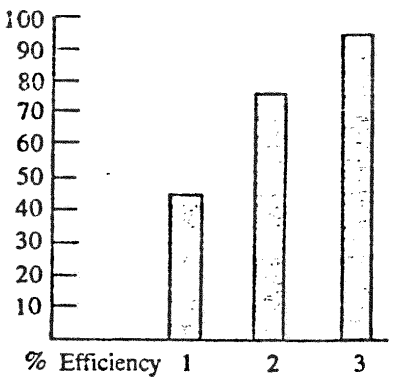

(1) Percentage of efficiency of domestic hot water system prior to program efforts. (2) Improvements in efficiency after cleaning combustion chambers and adjusting firing rate. (3) Further improvement after the insulation of hot water piping. Note that percentage of efficiency in what is, in most hotels and motels, the biggest factor in energy costs, was approximately doubled.

\section{CASE II}

\section{Ramada Inn-Airport, San Antonio, Texas}

The Ramada Inn-Airport, San Antonio, Texas has 200 guest rooms and sizable public areas consisting of a restaurant/kitchen, lounge, administrative offices, meeting rooms, lobby, and a laundry. The complex consists of five freestanding buildings and an outdoor swimming pool. The interior area of the total property is 111,425 square feet. The property is nineteen years old. 
"In 1972, the Ramada Inn-Airport, San Antonio, Texas, was paying in the order of eight mils ( 0.8 cents) a kilowatt hour for electricity and 3.5 cents a therm for natural gas. In 1978, these costs had increased to 3.5 cents/Kwh for electricity and 23 cents/therm for natural gas--representing a very substantial per unit cost increase. In 1978, the Ramada Inn-Airport consumed 1,475,952 $\mathrm{kwh}$ of electricity and 72,768 therms of natural gas. The total cost of electricity and natural gas was $\$ 68,305$. The cost of similar amounts in 1972 would have been $\$ 14,354$. This represents an increase in cost of $\$ 53,951$, or 376 percent." 5

Realizing the potential impact of increasing utility rates, the management took some steps that brought about substantial reduction in the consumption of utilities. For example, a comparison of the energy use between the years 1977 and 1978 revealed that, "in 1977 the property required $111,022 \mathrm{Btu} / \mathrm{sq}$. ft., while in 1978, the requirements decreased to $110,502 \mathrm{Btu} / \mathrm{sq}$. ft.--a reduction of $520 \mathrm{Btu} /$ sq. ft. Energy costs, even after increases in unit costs in 1978, remained virtually the same: $\$ 68,666$ in 1977, and $\$ 68,385$ in $1978 . " 6$

Thus, the above cases clearly show that it was the increasing cost of utilities that led the management to move in the direction of energy conservation and its efficient use.

5 Jack Wolfe, "The Ramada Inn-Airport, San Antonio, "A Case Study in Effective Energy Management," Lodging, May 1979, p. 30 .

$$
{ }^{6} \text { Ibid., p. } 32 .
$$




\section{THE RESEARCH METHODOLOGY}

Interviews were arranged with the management personnels. The questions asked during the interview process were in the form of a Questionnaire. The purpose of such a questionnaire was to maintain consistency and uniformity in the type of questions asked to the various hotel operators. The questions were carefully worded, which were intended to reveal more than the simple answers given.

The criteria for the properties to be selected were:

1. Hotels to be located within the City of Miami

2. Hotels to have 150 rooms or more.

The Dade County Tourist Accommodation Facilities Directory of 1980, published by the Metro Dade Department of Tourism was used as a primary source for the selection of the samples. The facilities are listed by the area they are located in and categorized as hotels and motels, (Refer to Appendix D).

The city limits of the City of Miami borders N.E. 87th Avenue in the north; Bettersea Road to the south. To the east, it borders MacArthur Causeway including the Dodge Island Seaport and Virginia Key; to the west it stretches up to W. 77th Avenue and 8th Street, (Refer to Appendix E).

Eighty-one hotels comprising 8399 rooms are located within the city limits. Of these, only 18 hotels have 150 rooms or more. Management of these 18 hotels was contacted for the purpose of the study. After evaluating their responses, 
the responses of 9 properties were selected as samples. These samples comprised 11 percent of the total hotels and 34 percent of the available hotel rooms, in the city of Miami.

The interpretation and the findings of these interviews are discussed below. 
Hypothesis I

The first hypothesis is that management is aware of the increasing cost of electricity and its impact on the property's operation.

From the interviews, it was evident that the management is aware of the increasing cost of electricity and its impact on their property's operation.

Due to the paucity of the numerical data, the hypothesis cannot be convincingly proved. However, the interpretation of the data obtained clearly supports the hypothesis.

Table 8 , shows that the electricity cost as a percentage of total energy cost has been increasing for the given properties.

\section{TABLE 8}

Electricity Cost as a Percentage of Total Energy Cost

\begin{tabular}{lcccc} 
Hotels & 1978 & 1979 & 1980 & 1981 (expected) \\
\hline 1 & N.A. & 30.0 & 14.0 & 14.0 \\
2 & 91.0 & 90.0 & 88.6 & N.A. \\
3 & N.A. & 84.0 & 89.0 & N.A. \\
4 & N.A. & 98.0 & 98.0 & N.A. \\
5 & N.A. & 95.0 & 95.0 & N.A. \\
6 & N.A. & N.A. & N.A. & N.A. \\
7 & 73.6 & 69.5 & 72.6 & 75.8 \\
8 & 95.0 & 95.0 & 92.0 & N.A. \\
9 & 89.3 & 90.4 & 91.3 & N.A.
\end{tabular}

$*_{\text {N.A. }}$ = Not Available 
Table 9, clearly shows that although the electricity cost has been increasing, its increases have larsol been at a decreasing rate, except for Hotel $¥ 5,8$ and $?$.

\section{TABLE 9}

\section{Electricity cost Increase ( $)$}

\begin{tabular}{|c|c|c|c|c|}
\hline Hotels & 1978 & 1979 & 1930 & :ris: wercted) \\
\hline 1 & N.A.* & 30.0 & 14.0 & $\therefore .0$ \\
\hline 2 & N.A. & 40.0 & 18.8 & $\therefore \therefore$ \\
\hline 3 & N.A. & 25.0 & 21.0 & $\because \Delta$ \\
\hline 4 & N.A. & 20.0 & 20.0 & $\because \lambda$. \\
\hline 5 & N.A. & 10.3 & 11.2 & $\therefore$ 交。 \\
\hline 6 & N.A. & N.A. & $\therefore A$. & $\therefore \ldots$. \\
\hline 7 & 19.8 & 14.2 & $\therefore . \therefore$. & 26.0 \\
\hline 8 & N.A. & 16.0 & 31.0 & $\therefore \therefore$ \\
\hline 9 & 7.3 & 20.0 & 40.0 & $\because$ in. \\
\hline
\end{tabular}

*N.A. = Not Available

In the case of Hotel \#5, the elect: " * * neasured by 11.2 percent in 1980 compared to $10.1 \% * \%$. Wowever, in the case of Hotels $\# 8$ and 9 , the c:...: : : cost increases nearly doubled-from 16 perc..." : to 31 percent in 1980 and from 20 percent in : " " percent in 1980 for Hotels $\# 8$ and 9 respectivn!

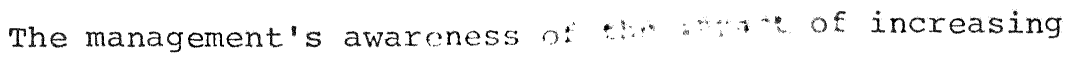

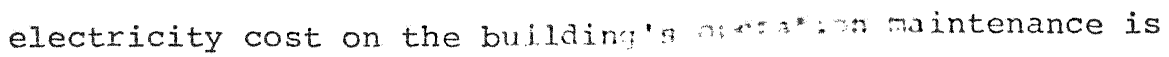

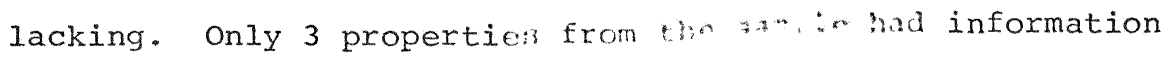
readily available on this aspect. 


\section{TABLE 10}

Effect of Electricity cost on Building Operation Maintenance Cost

\begin{tabular}{llrrlr} 
Hotel & 1978 & 1979 & 1980 & 1981 (ex ced) \\
1 & & & & & \\
2 & N.A.* & N.A. & N.A. & N.A. \\
3 & N.A. & 65.6 & 4.6 & 3.2 \\
4 & N.A. & 4.3 & 4.2 & N.A. \\
5 & N.A. & N.A. & N.A. & N.A. \\
6 & N.A. & N.A. & N.A. & N.A. \\
7 & N.A. & N.A. & N.A. & N.A. \\
8 & N.A. & N.A. & N.A. & N.A. \\
9 & N.A. & N.A. & N.A. & N.A. \\
\hline
\end{tabular}

*N.A. - Not Available 
Hypothesis II

The second hypothesis is that the management does not have any specific or concrete policies to control the consumption of electricity.

Referring to the Questionnaire in Appendix F, some questions were asked in order to determine the validity of the hypothesis. These questions are numbered 6 through 14. The results have been tabulated in Appendices G to $K$. Method of Determing Exact Energy Consumption

Only 22 percent of the properties from the sample have some method of determining exact energy cost. Implying thereby, that the management does not perceive the situation to be serious enough or critical to warrant any actions for determining the exact energy consumption by the various departments on the property.

Energy Consumption Allocation Based on Formula

Nearly twenty-two percent of the properties from the sample group allocate energy consumption based on formula or assumed consumption by the various departments of the hotel. The most common allocation is based on the assumption that rooms department consume nearly 80 percent of the total energy used.

\section{Energy Budget}

Seventy-seven percent of the sample properties do prepare energy budgets. The budget is based either at assumed 
inflation level or on the expected increases by the FP\&L. This has been in practice since their first day of operation. Unigue Idea Regarding Energy Conservation

None of the properties have come up with a unique idea regarding the conservation of energy, which could have contributed to the overall corporate policy.

Guidelines Regarding ROI/Payback Period

Thirty-three percent of the properties surveyed had certain guidelines laid down by the corporate office on the owners regarding the ROI or the payback period on energy related equipments. It is of interest to note that these properties were built in the mid or late seventies--the time of energy crisis and economic downturn. Thereby implying that the idea of energy conservation, efficient use of equipments and increasing electricity rates were considered. For example, one of the property's had to relate the ROI or the payback period on energy related equipment to the estimated sales. That is, if the addition of any equipment increased the sales than it was considered feasible to install such equipment. In another property, payback of 2 years or less was the basis of selecting equipments. One of the properties built in the early 70s, emphasized the payback period or ROI for the last 3 years only.

Measures Taken by the Managers to Control Energy Costs When the managers were asked about the various measures 
they have taken thus far to meet or control the increasing cost of electricity their responses indicated, it was only recently that they resorted to measures that would give them some indication as to the usage and control of electricity. The responses were as follows:

(a) Conduct Energy Audits

Nearly fifty percent of the properties conducted energy audits annually.

(b) Periodic Reading of the Electric Meters

In most cases, reading of electric meters by the hotel's personnel on a daily basis is a recent development. Earlier the readings by the FP\&L sufficed.

(c) Look Into the Various Electric Rate Options

None of the properties surveyed had looked into the various electric rate options.

(d) Keep a close Watch on Demand Rate

Only thirty percent of the properties kept a close watch on demana rates. Therefore, not on the list of high priorities.

(e) Caliberation of the Meters

None of the properties did the calibration of the meters on their own but left it to FP\&L to look after it.

(f) Energy Conservation Instruction to the Employees It was only within the last one year that the 
management instructed the employees in the basics of energy conservation.

(g) Inspection of EJectric Appliances

Sixty percent of the properties surveyed had their electric appliances inspected regularly by their staff.

(h) Inspection and Strict Control of the HUAC System The inspection and strict control of the HUAC system was practiced by sixty percent of the properties. The inspection is generally conducted on a bi-weekly basis.

(i) Use of 'Economizer' Equipments Only one property and that to recently has installed economizer units.

(j) Hire Outside Consultants to Evaluate and Suggest Remedial Measures

Only twenty percent of the properties had hired outside consultants recently, to inspect the physical plant and suggest remedial measures.

Thus from the above findings it is evident that the management at large do not have any concrete or specific plans to control the consumption of electricity. 


\section{OTHER FINDINGS}

1. In many instances the management was not aware of the simple ways of controling electricity costs.

2. Electricity is the major source of energy used by the properties, followed by natural gas and fuel oil.

3. On the average, 83 percent of the total energy usage comprises of electricity and approximately 15 percent is natural gas (See Appendix M).

4. On the average, nearly 75 percent of the electricity is consumed by the rooms (See Appendix I).

5. Airport area properties are less worried at this time about increasing electricity costs, primarily because of high occupancy around the year. To meet the increasing cost of operations, these properties have been able to increase their room rates, etc. without any negative effect on their occupancies.

6. Of the sample hotels, properties that were built before 1970, are faced with greater energy costs because of the lack of adequate energy conservation technology and lack of emphasis on energy conservation at that time. However, these properties are now refurbishing and installing efficient equipments.

\section{SUMMARY OF THE RESULTS}

The samples constitute 11 percent of the hotels and 34 percent of the available hotel rooms in the City of Miami. 
These properties have between 150 to 600 rooms. The results of the interview imply clearly that the maragement is aware of the impact of the increasing energy costs at large and electricity cost in particular and their impact on the property's operation. At this time, management at large do not have any specific or concrete plans to control and account for the consumption of electricity. However, it is only recently that the managements have started working towards specific plans to control and account for the consumption of energy. It is only a matter of time before such practices would become universal. 
SELECTED BIBLIOGRAPHY 


\section{SELECTED BIBLIOGRAPHY}

"A Dark Future for Utilities," Business Week, May 28, 1979.

Davis, Keith. Human Behavior at Work, 4 th Edition. New York: McGraw Hill Book Company, 1972.

Emory, William C. Business Research Methods. Homewood, Illinois: Richard D. Irwin., 1976.

Energy Technical Center--The Hospitality, Lodging, and Travel Research Foundation, Inc., "Analysis of the Energy Use of 284 Hotels and Motels 1979."

Florida Power and Light Company. Annual Report 1980.

Laventhol and Horwath, Certified Public Accountants. U.S. Lodging Industry Report 1976.

Laventhol and Horwath, Certified Public Accountants. U.S. Lodging Industry Report 1977.

Laventhol and Horwath, Certified Public Accountants. U.S. Lodging Industry Report 1978.

Laventhol and Horwath, Certified Public Accountants. U.S. Lodging Industry Report 1979.

Laventhol and Horwath, Certified Public Accountants. U.S. Lodging Industry Report 1980.

"Ia Quinta Motor Inn, San Antonio, A Case Study in Energy Management: Controlling the Cost of Utilities," Lodging, June 1979.

Leedy, Paul D. Practical Research: Planning and Design. New York: Macmillan Publishing Co., 1974.

Redlin, Michael H. "Energy Consumption in Lodging Properties: Applying Multiple-Regression Analysis for Effective Measurement," The Cornell H.R.A. Quarterly, February 1979.

Redlin, Michael H. and Jan A. deRoos, "Gauging Energy Savings: Further Application of Multiple-Regression Analysis," The Cornell H.R.A. Quarterly, February 1980.

Studness, Charles M. "Electric Demand and Aggregate U.S. Energy Consumption," Public Utilities Fortnightly, July $31,1980$. 


\section{SELECTED BIBLIOGRAPHY (continued)}

Whyte, William H. Jr. The Organization Man. New York: Simon \& Schuster, 1956.

Wolfe, Jack, "The Ramada Inn-Airport, San Antonio, A Case Study in Effective Energy Management," Lodging, May 1979. 
APPENDICES 
APPENDIX A

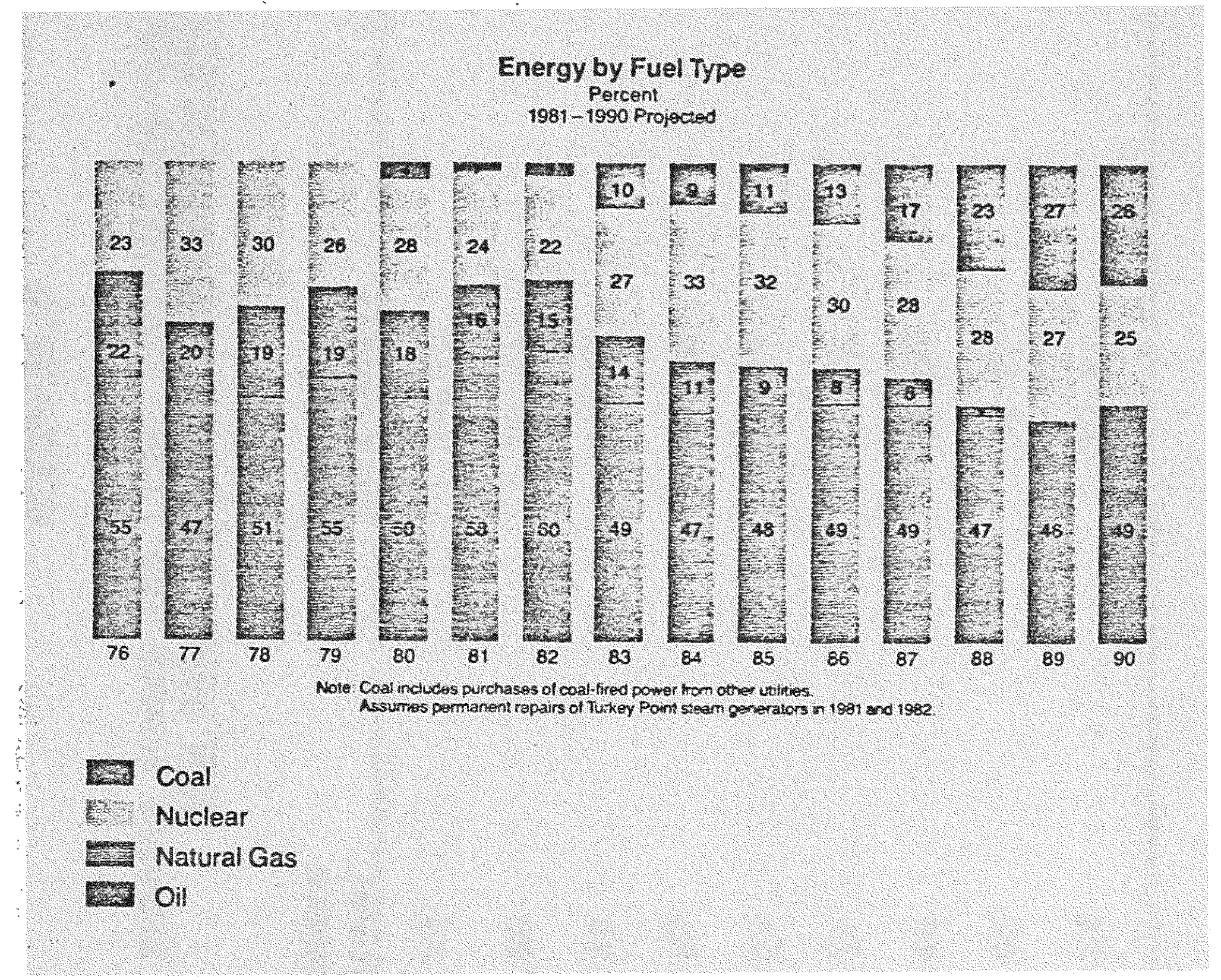




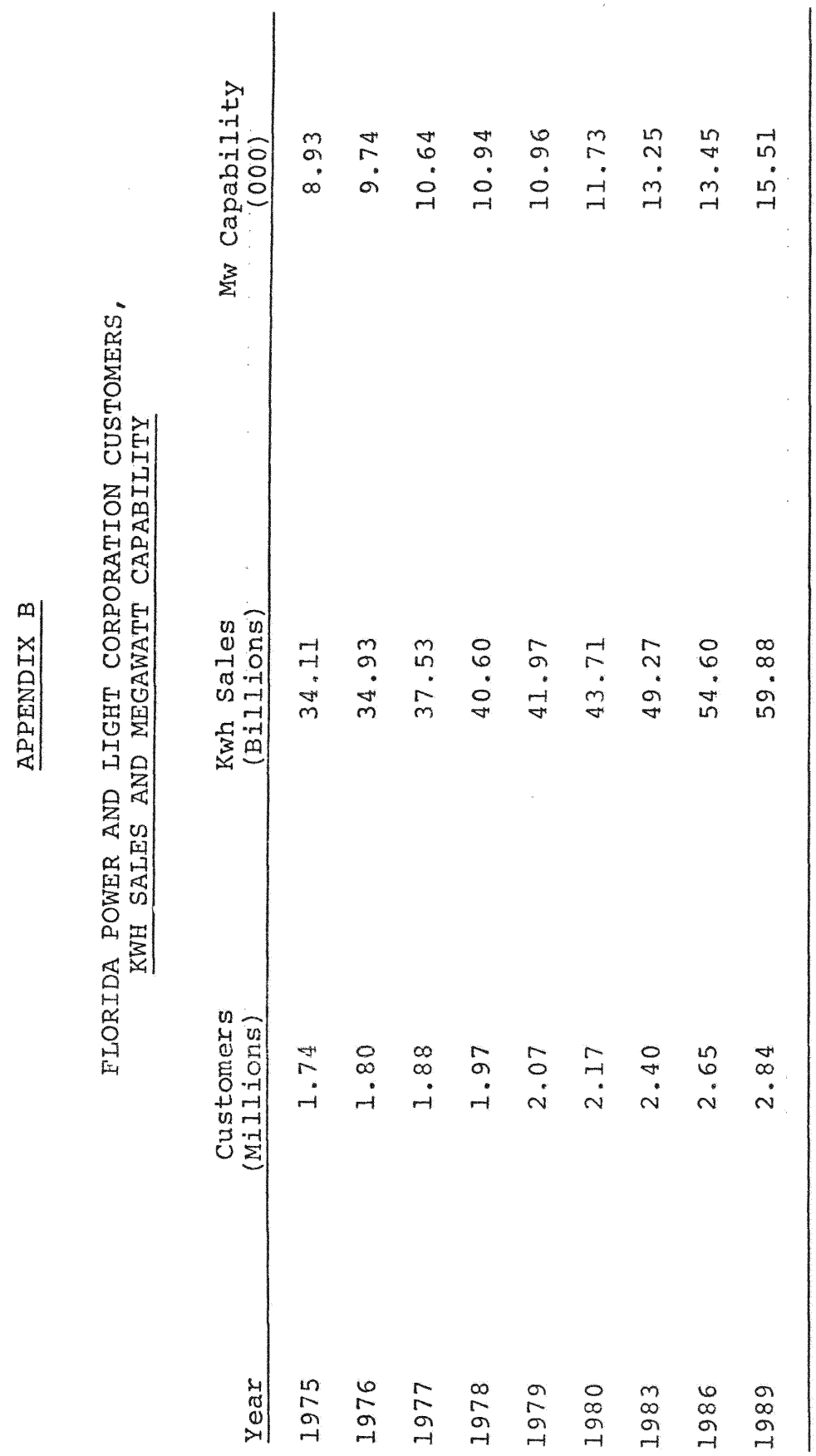


PER KWH

1973

1974

1975

1976

$$
\begin{aligned}
& \text { May } \\
& \text { June } \\
& \text { July } \\
& \text { August } \\
& \text { September } \\
& \text { October } \\
& \text { November } \\
& \text { December }
\end{aligned}
$$

$0<$

$.014 C$

.0148

$.071 \%$

$.086 \%$

$.087 \%$

.1248

.0818

.1836

$.216 \dot{C}$

$.378 \%$

.4736

.521 \&

$.571 \%$

$.639 \%$

$.8 \%$

$.784 \%$

$.919 \dot{c}$

$.919 \%$

.9198
*Frozen at october level.

* November

*December

$\begin{array}{lll}\text { January } & (12 / 27-1 / 27) & .847 \zeta \\ \text { February } & (1 / 28-2 / 25) & .784 \xi \\ \text { March } & (2 / 26-3 / 26) & .533 \xi \\ \text { April } & (3 / 27-4 / 24) & .575 \xi \\ \text { Apri1 } & (4 / 25-4 / 30) & .665 \xi \\ \text { May } & (5 / 1-5 / 31) & (.109 \xi) \\ \text { June } & (6 / 1-6 / 30) & .271 \xi \\ \text { July } & (7 / 1-7 / 31) & .367 \xi \\ \text { August } & (8 / 1-8 / 31) & .382 \xi \\ \text { September } & (9 / 1-9 / 30) & .123 \xi \\ \text { October } & (10 / 1-10 / 31) & .206 \xi \\ \text { Novernber } & (11 / 1-11 / 30) & .180 \xi \\ \text { December } & (12 / 1-12 / 31) & .110 \xi\end{array}$

PEP 1,000 KWH

$\begin{array}{lr}\$ & 0 \\ \$ & .14 \\ \$ & .14 \\ \$ & .71 \\ \$ & .86 \\ \$ & .87 \\ \$ 1.24 \\ \$ & .81\end{array}$

$\$ 1.83$

$\$ 2.16$

$\$ 3.78$

$\$ 4.73$

$\$ 5.21$

$\$ 5.71$

$\$ 6.39$

$\$ 8.00$

$\$ 7.84$

$\$ 9.19$

$\$ 9.19$

$\$ 9.19$

$\$ 8.47$

$\$ 7.84$

$\$ 5.33$

$\$ 5.75$

$\$ 6.65$

(\$1.09)

$\$ 2.71$

$\$ 3.67$

$\$ 3.82$

$\$ 1.23$

$\$ 2.06$

$\$ 1.80$

$\$ 1.10$

$\$ 1.27$

$\begin{array}{llcr}\text { January } & (1 / 1-1 / 31) & .127 \xi & \$ 1.27 \\ \text { February } & (2 / 1-3 / 1) & .092 \xi & \$ .92 \\ \text { March } & (3 / 2-3 / 31) & (.070 \xi) & (\$ .70) \\ \text { April } & (4 / 1-4 / 30) & (.094 \xi) & (\$ .94) \\ \text { May } & (5 / 1-5 / 31) & (.132 \xi) & (\$ 1.32) \\ \text { June } & (6 / 1-6 / 30) & (.042 \xi) & (.42) \\ \text { July } & (7 / 1-7 / 31) & .207 \xi & \$ 2.07 \\ \text { August } & (8 / 1-8 / 31) & .167 \xi & \$ 1.67 \\ \text { September } & (9 / 1-9 / 30) & .141 \xi & \$ 1.41 \\ \text { October } & (10 / 1-10 / 31) & .248 \xi & \$ 2.48 \\ \text { November } & (11 / 1-11 / 30) & .310 \xi & \$ 3.10 \\ \text { December } & (12 / 1-12 / 31) & .079 \xi & \$ .79\end{array}$


Residential Base Bill

For 1,000

Per kwh

January

February

March

April

May

June

July

August

September

october

November

December

January

February

March

April

May

June

July

August

September

october

Novembex

December

January

February

March

April

May

June

July

August

September

October

November

December
(1/1-1/31)

$(2 / 1-3 / 1)$

$(3 / 2-3 / 31)$

$(4 / 1-5 / 1)$

(5/2-5/31)

$(6 / 1-6 / 30)$

$(7 / 1-8 / 1)$

(8/2-8/31)

$(9 / 1-10 / 2)$

(10/3-10/31)

(11/1-11/30)

$(12 / 1-1 / 2)$

$(1 / 3-1 / 30)$

$(1 / 31-3 / 1)$

$(3 / 2-3 / 3 i)$

(4/1-5/1)

(5/2-5/31)

$(6 / 1-6 / 30)$

$(7 / 1 \div 8 / 1)$

(8/2-8/31)

(9/1-10/2)

(10/3-10/31)

(11/1-12/1)

$(12 / 2-1 / 2)$

$(1 / 3-1 / 31)$

$(2 / 1-3 / 1)$

$(3 / 2-3 / 31)$

$(4 / 2-4 / 30)$

$(5 / 1-5 / 31)$

$(6 / 1-7 / 1)$

$(7 / 2-7 / 31)$

(8/1-8/30)

$(8 / 31-10 / 1)$

$(10 / 2-10 / 31)$

$(11 / 1-12 / 2)$

$(12 / 3-1 / 1 / 80)$
.3968

$.278 \%$

.222 \&

(.224\%)

(.173द)

$.039 \dot{8}$

.0826

$.353 \%$

.4116

$.185 \%$

$.063 \dot{\phi}$

(.103\%)

(.133\%)

.0136

$.089 \%$

$.188 \%$

(.214\%)

$.005 \%$

.2826

.1618

$.177 \%$

.2856

$.307 \%$

(.029)

(.076\&)

$.079 \%$

.265 c

.2984

.2798

$.978 \%$

.865 \&

1. 118

$.801 \%$

$.943 \dot{8}$

$.948 \%$

.7996
Fer $1,000 \mathrm{kWh}$

$\$ 3.96$

$\$ 2.78$

$\$ 2.22$

(\$2.24)

(\$1.73)

$\$ .39$

$\$ .82$

$\$ 3.53$

$\$ 4.11$

$\$ 1.85$

$\$ .63$

(\$1.03)

(\$1.33)

$\$ 13$
$\$ .89$

$\$ 1.88$

(\$2.14)

$\$ .05$

$\$ 2.82$

$\$ 1.61$

$\$ 1.77$

$\$ 2.85$

$\$ 3.07$

(\$. 29)

(\$.76)

$\$ .79$

$\$ 2.65$

$\$ 2.98$

$\$ 2.79$

$\$ 9.78$

$\$ 8.65$

$\$ 11.18$

$\$ 8.01$

$\$ 9.43$

$\$ 9.48$

$\$ 7.99$ kvin

$\$ 38.93(1)$

$37.09(2)$

$36.53 / 39.31 .(3)$

34.85

35.36

37.48

$37.91 / 39.80(4)$

42.51

43.09

40.83

39.61 .

37.95

$\$ 37.65$

$\$ 39.11$

$\$ 39.87$

$\$ 40.86$

$\$ 36.84$

$\$ 39.03$

$\$ 41.80$

$\$ 40.59$

$\$ 10.75$

$\$ 41.83$

$\$ 42.05$

$\$ 38.69$

$\$ 38.22$

$\$ 39.77$

$\$ 41.63$

$\$ 41.96$

$\$ 41.77$

$\$ 48.76$

$\$ 47.63$

$\$ 50.16$

$\$ 46.99$

$\$ 18.41$

$\$ 48.46$

$\$ 46.97$

(1) Base charge is $\$ 34.97$ fuel adjustment for January, 1977

(2) Base charge is $\$ 34.31 \mp$ fuel adjustment for $2 / 1 / 77-3 / 13 / 77$

(3) Base charge is $\$ 37.09 \mp$ fuel adjustment for $3 / 14 / 77-7 / 7 / 77$

(4) Base charge is $\$ 38.98 \pm$ fuel adjustment for $7 / 8 / 77$ - present 
Residential

Base Bill

January

February

$(1 / 2-1 / 31)$

$(2 / 1-3 / 2)$

$(3 / 3-3 / 31)$

March

April I through

September 30 (Adjusted)

october - November

December - March 1981

MARCH'S1-APRiL 1981
$.359 \xi$

.9926

$1.073 \xi$

1. 475

1. 160

1. 320

1.950
$\$ 3.59$

$\$ 9.92$

$\$ 10.73$

\$14.75

$\$ 11.60$

$\$ 13.20$

19.50 $\mathrm{kWh}$

$\$ 42.57$

$\$ 48.90$

$\$ 49.71$.

$\$ 53.73$

$\$ 50.58$

$\$ 52.18$

58.48

Base charge is $\$ 38.98 \pm$ fuel adjustment for $7 / 8 / 77$ - present 


\begin{tabular}{|c|c|c|c|c|c|c|}
\hline \multirow[b]{2}{*}{ Area $+*$} & \multicolumn{2}{|c|}{ Hotels } & \multicolumn{2}{|c|}{ Motels } & \multicolumn{2}{|c|}{ Total } \\
\hline & Number & Units & Number & Units & Number & Units \\
\hline Miami Beach & 320 & 29,174 & 23 & 1,497 & 343 & 30,671 \\
\hline Surfside/Bal Harbour & 13 & 1,943 & 25 & 1,134 & 38 & $3,07 i$ \\
\hline Sunny Isles & 6 & 1,036 & 55 & 6,245 & 61 & 7,281 \\
\hline North Dade & 19 & 1,398 & 112 & 4,617 & 131 & 6,015 \\
\hline Airport & 10 & 2,023 & 10 & 1,217 & 20 & 3,240 \\
\hline Downtown & 56 & 5,174 & 8 & 569 & 64 & 5,743 \\
\hline Key Biscayne & 3 & 604 & 7 & 314 & 10 & 918 \\
\hline South Dade & 18 & 1,089 & 94 & 2,657 & 112 & 3,746 \\
\hline TOTAL & 445 & 42,441 & 334 & 18,250 & 779 & 60,691 \\
\hline
\end{tabular}

*Includes only those tourist accommodation facilities classified and licensed either as hotels or motels by the State of Florida Department of Business Regu. lation, Bureau of Licensing, Division of Hotels and Restaurants, as of Februarj 1980.

**Area as defined according to the following definitions:

Miami Beach: All tourist facilities in the corporate limits from Government Cut on the south to 87th Terrace on the north.

Surfside/Bal Harbour: All tourist facilities located within the corporate limits of both municipalities from 88th Street on the north to Baker's Haulover Cut.

Sunny isles: All tourist facilities located from Haulover Beach north to the Broward County Line east of Biscayne Bay and the Intracoastal.

North Dade/Other: All tourist facilities located from Flagler Street on the sout to the Broward county 7 ine exclusive of the following areas: Downtown, Airport, Miami Beach, SurfsidejBal Harbour and Sunny Isles.

Airport: All tourist facilities located from Flagler Street on the south to the Iiami Canal on the noth and from the Palmetto Expressway on the west to N.W. 37th Avenue or: the east.

Downtowr: All tourist facilities located from I-95 on the west to Biscayne Bay or the east and S.W. 12th Street on the south to N.W. 36th Street on the north.

- Key Biscayne: All tourist facilities located on Key Biscayne including Virginia Key and the entrance to the Rickenbacker Causeway.

South Dade/0ther: All tourist facilities located south of Flagler Street to the Monroe County Line excluding Key Biscayne and the Downtown Area. 


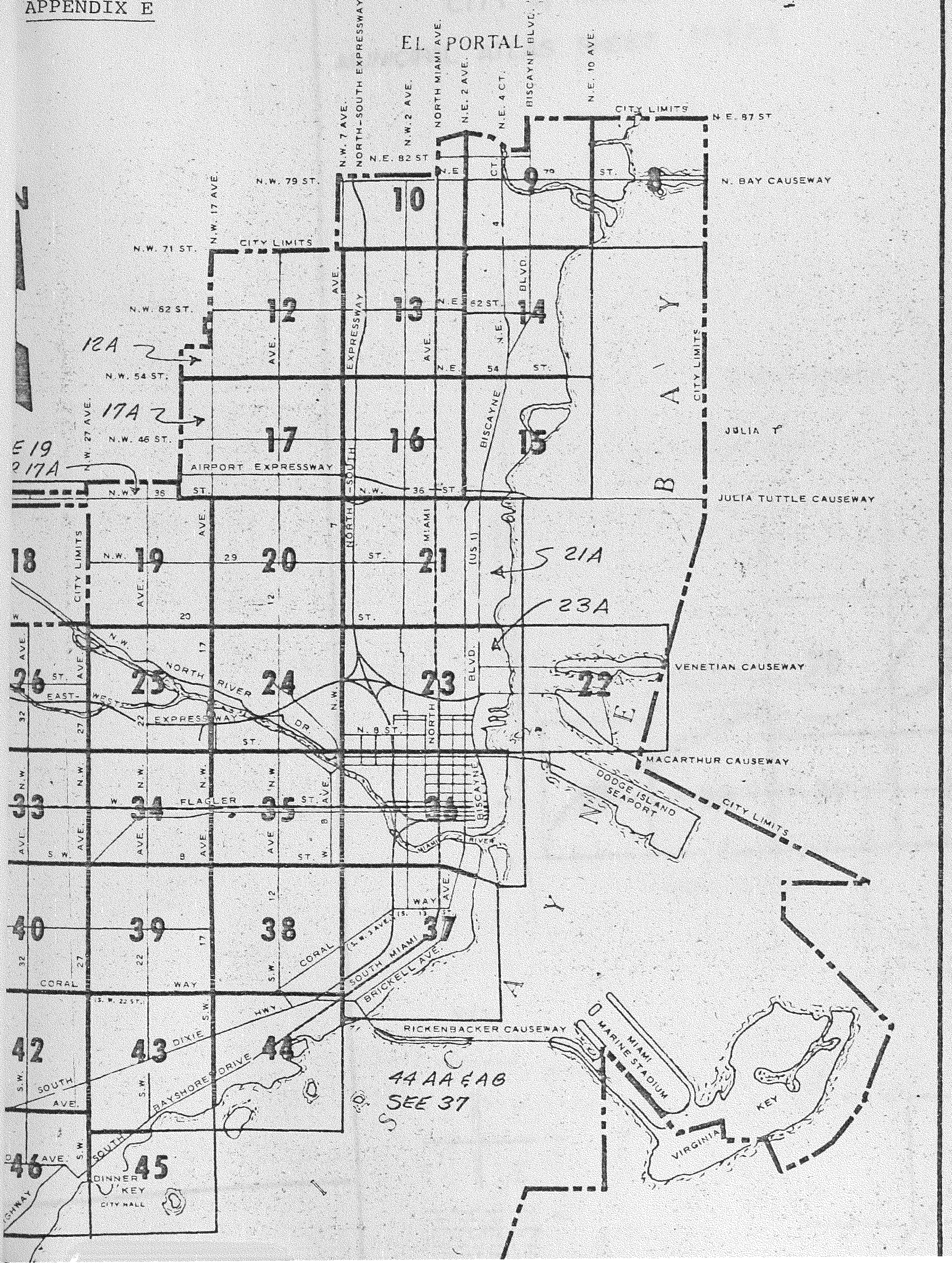


CITY of MIAMI, FLORIDA

MUNICIPAL ATLAS SHEET INDEX

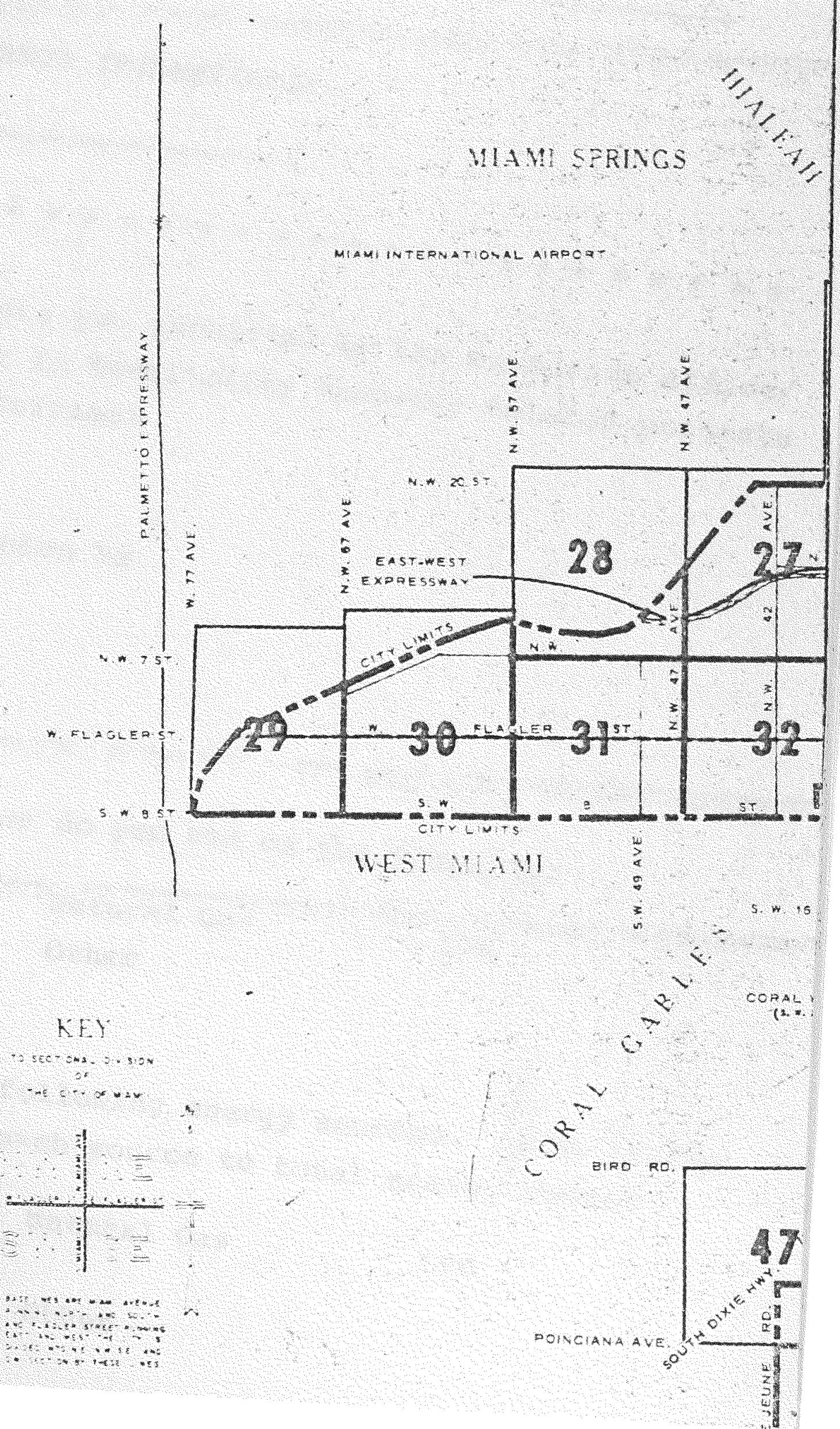


NARE OF THE PROPERTY

BOIIT:

DESIGVATION OF THE PERSON INTERVIEVED:
LOCATED AT:

NUMBER OF ROCHS:

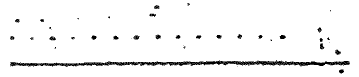

2. :ill your participation be

i. Active

ii. Passive

3. What forms of energies do you use on the property?

Electricity

Fuel oil ivatural Gas

Other

4. Consider each of the following energy sources. What is the approxirrate ratio of each source to total energy costs?

Electricity

Natural Gas

LPG 
5. Over the last i years, by how much (approximate percentage) has the Property's electricity cost gone up by?

\begin{tabular}{ll} 
Year. & $\begin{array}{l}\text { of Total } \\
\text { Energy Cost }\end{array}$ \\
\hline
\end{tabular}

$1977-78$

$1978-79$

$1979-80$

$2980-8 i^{\circ} \cdot($ expected)

6(i): In your control program, do you have a method of determinins the exact energy consumption in any of the following areas? Poons, Cooking, Dishwashing, Restaurant, Iobjy, Laundxy, Exterior Iiqhting, Any Other area(s).

YES

NO

6(ii). If Yes, when did you begin using exact controls

7(i). If the answer to question number $6(i)$ is No; then do you. allocate Enerqy consunotion on a formula basis?. YES

NO

$7(i i)$. Could you give me sone insight into the basis of the Formula which you use?

8. Please give me some idea (approximate percentage) about the consumpition of electricity in the following areas: 
8. (continued)

cookings

$\%$

Dishrasing 응

Restaurant $\%$

Iobby. -

Laundry $\therefore$

Any Other uses .

9. Do you prepare short and long term energy budgets for the Property's electricity consurption?

XES

No

In The Process of Formulatio

10. İ Yes, when was this policy implenented?

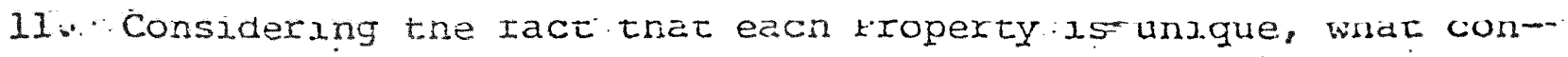
tributions have come fron this property that have contributed to the overall corporate policy related to Energy conservatior and usage?

12. Considering the possible seriousness of the energy probleins that may develop unexpectedly. what would you do on a persone basis if you are faced with continuous crisis such as BrownOuts ano Blackouts? 
13(i). Axe there any guidelines that you follow or that are suggested by the corporate office/Owners regarding the R.O.I. or Payback on energy related equipments?

13(ii). If Yes, when did tne company Implement these Policies?

13(iii). Could you give me some examples of the kinds of policies under which you operate?

14. To meet the increasing cost of electricity which of "the following measures do you take?

a. Conduct energy audits

b. Feriodic readings of the electric meters

c. Look into the various electric rate options

d. Keep a close watch on the Demand rate

e. Caliberation of the meters

f. Energy conservation instruction to the employees 
34. (continued)

g. Inspection of the electric appliances

h. Inspection and strict control of the HVAC System

I. Use of 'economizer' ecuioments

j. Hire outside consultants to evaluate and suorest rernedial measures

k. Any other meàsüres

13. kecently a number of Codes have been madified or promulgated. A number of these codes have' a great impact on the use of Electricity by the hotels. Some of these codes are, A.S.H.R.A.E. 90-75-76...., Modification of the Model Life Safety Code, i.e., Emergency Building Temperature Restriction Modification of the Public Health Code related to the minimum cemperature of water for rinsing, etc.

How do these codes affect your Property?

A.S.H.R.A.E. $90-75-76$..

Emergency Building Temperature Restriction 
15. (continued)

Puivic Health Code

16(i). Has the increasing electricity cost, increased, decreased or has not attected the Building operation maintenance?

16(ii). If increased or decreased, then by how much? $1977-78$

1978-79

$$
1979-80
$$

\section{0-8I (expected)}

I7(i). Has the electricity cost as a percentaqe nf Net income increased; decreased or remained the same?

17(ii). If increased or decreased, then by. how much?

$1977-78$

$1979-79$

$1979-80$

1980-81 (expected) 
APPENDIX G

METHOD OF DETERMINING EXACT ENERGY

CONSUMPTION BY VARIOUS DEPARTMENTS

Hotel

Yes

No

\begin{tabular}{lll}
1 & - & $x$ \\
2 & $x$ & - \\
3 & - & - \\
4 & - & - \\
5 & - & - \\
6 & $x$ & $x$ \\
7 & - & $x$ \\
8 & - & - \\
9 & & \\
\hline
\end{tabular}




\section{APPENDIX H \\ ENERGY CONSUMPTION \\ ALLOCATION}

Hotel

Yes

No

\begin{tabular}{lll}
1 & - & $\mathrm{x}$ \\
2 & - & $\mathrm{x}$ \\
3 & - & $\mathrm{x}$ \\
4 & - & - \\
5 & - & $\mathrm{x}$ \\
6 & - & - \\
7 & $\mathrm{x}$ & $\mathrm{x}$ \\
8 & - & - \\
9 & $\mathrm{x}$ & - \\
\hline
\end{tabular}

APPENDIX I

ELECTRICITY USAGE (\%) BY ROOMS

AND OTHER DEPARTMENTS

\begin{tabular}{crrrr} 
Hotel & Rooms & Other \\
\hline 1 & N O T D I V I D E D \\
2 & 95 & & & 5 \\
3 & 70 & & & 30 \\
4 & 75 & & & 25 \\
5 & 75 & & 25 \\
6 & 85 & & 15 \\
7 & 85 & & 15 \\
8 & 80 & & 20 \\
9 & 80 & & 20 \\
& & & \\
\hline
\end{tabular}




\section{APPENDIX J}

\section{ENERGY BUDGETING}

\begin{tabular}{ccc} 
Hotel & Yes & No \\
\hline 1 & - & x \\
2 & $x$ & - \\
3 & $x$ & - \\
4 & - & - \\
5 & $x$ & - \\
6 & $x$ & - \\
7 & $x$ & - \\
8 & $x$ & - \\
9 & $x$ & \\
\hline
\end{tabular}

\section{APPENDIX $\mathrm{K}$}

GUIDEIINES BY CORPORATE OFFICE

FOR ROI/PAYBACK PERIOD

\begin{tabular}{ccc} 
Hote1 & Yes & No \\
\hline 1 & - & $\mathrm{x}$ \\
2 & - & $\mathrm{x}$ \\
3 & - & $\mathrm{x}$ \\
4 & - & - \\
5 & $\mathrm{x}$ & - \\
6 & - & - \\
7 & $\mathrm{x}$ & - \\
8 & $\mathrm{x}$ & $\mathrm{x}$ \\
9 & - & \\
\hline
\end{tabular}




\section{APPENDIX L}

\section{FORMS OF ENERGY USED}

Hotel Electricity Nat. Gas. IPG Fuel Oil

$\begin{array}{lllll}1 & x & x & - & - \\ 2 & x & - & x & - \\ 3 & x & x & - & - \\ 4 & x & x & - & - \\ 5 & x & x & - & - \\ 6 & x & x & - & - \\ 7 & x & x & - & - \\ 8 & x & x & - & -\end{array}$

\section{APPENDIX M}

PERCENTAGE OF EACH SOURCE

OF ENERGY USED

Hotel Electricity Nat. Gas. LPG Fuel Oil

$\begin{array}{rrrrr}1 & 83.0 & 17.0 & - & - \\ 2 & 82.0 & - & 8.0 & 10 \\ 3 & 76.0 & 24.0 & - & - \\ 4 & 95.0 & 5.0 & - & - \\ 5 & 90.0 & 10.0 & - & - \\ 6 & 90.0 & 10.0 & - & - \\ 7 & 61.5 & 38.5 & - & - \\ 8 & 90.0 & 10.0 & - & - \\ 9 & 80.0 & 20.0 & - & -\end{array}$

